\author{
Case Study \\ www.ijrap.net (ISSN:2229-3566)
}

\title{
AYURVEDIC MANAGEMENT OF SACROILIITIS: A CASE STUDY
}

Gahalawat Preeti ${ }^{* 1}$ and Kumar Pankaj ${ }^{2}$

${ }^{1}$ Final Year Student, Ayujyoti Ayurvedic College and Hospital, Sirsa, Haryana, India

${ }^{2}$ Assistant Professor, Department of Panchakarma, Ayujyoti Ayurvedic College and Hospital, Sirsa, Haryana, India

Received on: 21/01/20 Accepted on: 21/03/20

\author{
*Corresponding author \\ E-mail: preetimanpreet157@gmail.com
}

DOI: 10.7897/2277-4343.110349

\begin{abstract}
Sacroiliitis is a condition caused by inflammation within the sacroiliac joint. It is commonly related to the amount of pressure that is put on to the sacroiliac joint. About $10-25 \%$ of cases are found to be associated with lower back pain. Up to $50 \%$ cases have radiation to lower extremity. Symptoms include prolonged inflammatory pain in low back region, hips or buttocks. A 27 years old male patient from Rohtak, Haryana, India was suffering from severe low back pain radiating to bilateral thighs from last 3 months. Patient was also suffering from Insomnia since last 6 months. SLR, Faber and Bragard tests were done. Only Faber test was found positive on left side. Patient also showed symptoms of Pitta vridhi like Santapa (daha), Alapnidrata and balahani so finally as per all sign and symptoms it was diagnosed as Pittaja Katishoola. In the present study the treatment planned was mainly with Dashmooladi ksheer Basti and Kati Basti. Because of this protocol patient got $90 \%$ relief in all sign and symptoms in 13 days and full relief in one month. In this case the treatment given pacifies Vata Dosha along with Pitta Dosha due to the Guna and Karma of formulations like Dashmoola pacifies Vata Dosha and along with ksheer it also pacifies Pitta Dosha.
\end{abstract}

Keywords: Pittaja katishoola, Dashmooladi Ksheer Basti, Sacroiliitis.

\section{INTRODUCTION}

Sacroiliac pain prevalence varies widely. Some studies report as $10-25 \%$ of those with lower back pain. In those with a confirmed diagnosis the presentation of pain with ipsilateral buttocks (94\%) and midline lower lumbar area $(74 \%)$. Up to $50 \%$ cases have radiation to lower extremity, $6 \%$ to the upper lumbar area, $4 \%$ to the groin and $2 \%$ to the lower abdomen. ${ }^{1}$

The inflammation of sacroiliac joint is known as Sacroiliitis. In this one or both sacroiliac joint becomes inflamed. Sacroiliitis may occur due to Ankylosis Spondylitis, Osteoarthritis and any traumatic injury that damage sacroiliac joint, due to strengthening of sacroiliac joint in pregnancy, any inflammation, UTI etc.

Main symptoms of Sacroiliitis include stiffness in lower back and buttocks. Pain also radiate to one or both legs. The pain in Sacroiliitis may aggravate during long time sitting or standing, running, fast walking, turning over in bed, stairs climbing and standing with giving weight on one leg for long time. ${ }^{2}$

On the basis of sign and symptoms Sacroiliitis is very similar to Katishoola in Ayurveda. The patient also showed symptoms of Pitta vridhi ${ }^{3-5}$ like Santapa (daha), Shoola, Alapnidrata, balahani so finally as per all sign and symptoms it was diagnosed as Pittaja Katishoola.

\section{MATERIAL AND METHODS}

A 27 years old male patient from Rohtak, Haryana attended our OPD on 22/5/2019 and he was suffering from severe low back pain radiating to bilateral thighs from last 3 months. Patient was also suffering from Insomnia since last 6 months. He consulted Allopathic physicians many times but he got only temporary relief with painkillers. Then he switched over to Ayurvedic treatment. He was admitted in hospital for treatment, after 13 days of treatment he got marked relief $(90 \%)$ in pain and daha and his quality of life also improved.

Study is carried out as per International conference of Harmonization-Good Clinical Practices Guidelines (ICH-GCP) or as per Declaration of Helsinki guidelines.

\section{Physical examination}

SLR, Faber and Bragard tests were done. Only Faber test was found positive on left side.

\section{Investigations}

MRI both sacroiliac joints revealed - Altered marrow signal intensity along sub chondral aspect of bilateral sacral ALA and adjacent iliac bones with fatty marrow and sclerotic changes along with mild exercises, more prominent on iliac aspect. These findings are suggestive of acute or chronic bilateral Sacroiliitis. Patient was found of kaphapittaja prakriti with madhyama ahara and vyayama Shakti. His Vata Dosha was found vitiated along with Pitta and were vitiating Asthi Dhatu. Srotas involved was Asthivaha and Srotodushti is of Sanga type. On the basis of findings, in Ayurveda it was diagnosed as Pittaja katishoola (Sacroiliitis) and treatment was given. 


\section{Treatment}

Table 1: Shodhana Chikitsa

\begin{tabular}{|c|c|c|}
\hline 1. & Sarwanga Abhyanga & Dhanvantara Taila \\
\hline 2. & Kati Basti & Kottamchukadi and Dhanvantara Taila \\
\hline 3. & Sarwanga Bhashpa Swedana & \\
\hline 4. & $\begin{array}{c}\text { Dashmooladi Ksheer Basti } \\
\text { Honey }-100 \mathrm{ml} \\
\text { Saindhav }-6 \mathrm{gm}\end{array}$ & \\
& $\begin{array}{c}\text { Sneha (Dhanvantara taila) }-70 \mathrm{ml} \\
\text { Kalka (Madanphala, Shatpushpa, kustha, } \\
\text { ashwagandha) }-30 \text { gm }\end{array}$ & \\
& Ksheerpaka (Dashmoola Kwath) $-350 \mathrm{ml}$ & \\
\hline 5. & Anuwasana Basti & Dhanvantara Taila \\
\hline
\end{tabular}

\section{Shaman Aushadhas}

Table 2: Shamana Chikitsa

\begin{tabular}{|c|c|c|c|}
\hline 1. & Vishmustika vati & $1 \mathrm{BD}$ & After Food \\
\hline 2. & Mahayogaraja Guggulu & $2 \mathrm{BD}$ & After food \\
\hline 3. & Sahacharadikashaya $^{7,8}$ & $15 \mathrm{ml}$ TID & Before Food \\
\hline
\end{tabular}

Anuwasana Basti was given in evening on the same day. During the whole period of treatment, patient was strictly advised to take rest, avoid oily and deep fried food, cold items and avoid cold exposure, cold water bath. Patient was asked to take light diet.

\section{Grading parameters}

\section{Radiating Pain}

Table 3: Radiating Pain

\begin{tabular}{|c|c|}
\hline 0 & No Radiating Pain \\
\hline 1 & Pain Radiating Up to Thigh \\
\hline 2 & Pain Radiating Up to Knee Joint \\
\hline 3 & Pain Radiating Up to Ankle Joint \\
\hline 4 & Pain radiating up to toe ${ }^{9}$ \\
\hline
\end{tabular}

Total sleep duration

Table 4: Total sleep duration

\begin{tabular}{|c|c|}
\hline 0 & Sufficient \\
\hline 1 & Slightly Insufficient \\
\hline 2 & Markedly Insufficient \\
\hline 3 & Very insufficient or did not sleep at all \\
\hline
\end{tabular}

Pain

Table 5: Pain

\begin{tabular}{|c|c|}
\hline 0 & $100 \%$ relief \\
\hline 1 & $80 \%$ relief \\
\hline 2 & $60 \%$ relief \\
\hline 3 & $40 \%$ relief \\
\hline 4 & $20 \%$ relief \\
\hline 5 & No relief $/$ Severe pain \\
\hline
\end{tabular}

Daha

Table 6: Daha

\begin{tabular}{|l|c|}
\hline 0 & Absent \\
\hline 1 & Intermittent \\
\hline 2 & Moderate \\
\hline 3 & Severe \\
\hline
\end{tabular}

Osha Chosa

Table 7: Osha Chosa

\begin{tabular}{|c|c|}
\hline 0 & Absent \\
\hline 1 & Mild \\
\hline 2 & Moderate \\
\hline 3 & Severe \\
\hline
\end{tabular}

\section{RESULT AND DISCUSSION}

Table 8: Result and Discussion

\begin{tabular}{|c|c|c|}
\hline & Before Treatment & After Treatment \\
\hline SLR & Negative & Negative \\
\hline FABER & Positive on left & Negative \\
\hline BRAGARD & Negative & Negative \\
\hline
\end{tabular}

Table 9: Result and Discussion

\begin{tabular}{|c|c|c|}
\hline Daha & 2 & 0 \\
\hline Osha Chosa & 2 & 0 \\
\hline Total sleep Duration & 3 & 0 \\
\hline Pain & 5 & 0 \\
\hline Radiating pain & 4 & 0 \\
\hline
\end{tabular}


Patient was feeling much better so discharged with Shamana Aushadh for another 20 days. After second follow up there was $100 \%$ relief in all sign and symptoms.

In this case of Pittaja Katishoola the main Shodhana procedure which is adopted here is Dashmooladi Ksheerbasti. Here Dashmoola pacify all the three Doshas because of combination of Laghu and Brihat panchmoola. When this Dashmoola combines with Ksheera and other Basti ingredients like honey, Saindhav, Sneha and Kalka Dravyas it predominantly acts on pitta and vata doshas especially on Asthi and Majja Dhatu.

Sahacharadi Kashaya very widely used in radiating pain like conditions because of its Ushna and Tikshna Guna whereas Mahayograja Guggulu calms all the three doshas along with Rasayana effect specially act on muscle and joint. Dhawantari taila pacifies the vata and pitta dosha because of its ingredients and the way of preparation. On the same hand Kottamchukadi taila pacifies the vata dosha because of Ushna tikshna nature.

\section{CONCLUSION}

All the above adapted treatment pacifies vata along with pitta dosha because of their Guna and Karma. Hence Dashmooladi Ksheerbasti could be a good line of treatment with other suitable procedures in Pittaja Katishoola or Sacroiliitis.

\section{REFERENCES}

1. Benjamine K. B, Matthew V. Sacroiliitis. William Beaumont Army Medical Centre. Cited 2019 February 15. Available from: https://www.ncbi.nlm.nih.gov.

2. Lana Burgess. What is Sacroiliitis Internet. Medical News Today. Cited 2017 November 11. Available from: www.medicalnewstoday.com.

3. Sushruta, Doshadhatumalakshayavridhivigyaniyaadhyay. In: Ayurveda Tattva Sandipika Hindi Commentary, Kaviraja
Ambikadutta Shastri, Sushruta Samhita Purvardha Sutra sthana, reprint edition. Varanasi: Chaukhambha Sanskrit Sansthan; 2018. p. 78, 15: 18.

4. Vagbhata, Doshadivigyaniyaadhyay. In: Vidyotini Hindi Commentary, Kaviraja Atridev Gupta, Ashtanga Hridaya, Sutra sthana, reprint edition. Varanasi: Chaukhambha Prakashan; 2019. p. 115, 11: 6.

5. Charaka, Kiyantashirshiyaadhyay. In: Vidyotini Hindi commentary, Pandit Kashinath Shastri, Dr. Gorakhnath Chaturvedi, Charaka Samhita Purvardha Sutra sthana, reprint edition. Varanasi: Chaukhambha Bharati Academy; 2015. p. 344, 17: 48.

6. Charaka, Vatashonitchikitsaadhyay. In: Vidyotini Hindi commentary, Pandit Kashinath Shastri, Dr. Gorakhnath Chaturvedi, Charaka Samhita Uttarardha Chikitsa sthana, reprint edition. Varanasi: Chaukhambha Bharati Academy; 2017. p. 835, 29: 124.

7. Vagbhata, Vatavyadhichikitsaadhyay. In: Vidyotini Hindi Commentary, Kaviraja Atridev Gupta, Ashtanga Hridaya, Chikitsa sthana, reprint edition. Varanasi: Chaukhambha Prakashan; 2019. p. 573, 21: 70.

8. Charaka, Vatavyadhichikitsaadhyay. In: Vidyotini Hindi commentary, Pandit Kashinath Shastri, Dr. Gorakhnath Chaturvedi, Charaka Samhita Uttarardha Chikitsa sthana, reprint edition. Varanasi: Chaukhambha Bharati Academy; 2017. p. 802, 28: 144.

9. Sathavane G.V, Pandya D.H, Baghel M.S. Effect of Vatari Guggulu in the management of Gridhrasi. AYU serial online 2015 cited 2020 Feb.27; 36: 41-5. Available from: http//www.ayujournal.org/text.asp?2015/36/1/41/169019.

\section{Cite this article as:}

Gahalawat Preeti and Kumar Pankaj. Ayurvedic management of Sacroiliitis: A Case Study. Int. J. Res. Ayurveda Pharm. 2020; 11(3):7-9 http://dx.doi.org/10.7897/2277-4343.110349 the site content and articles published. The views expressed in articles by our contributing authors are not necessarily those of IJRAP editor or editorial board members. 